\title{
THE IMPLICATIONS OF FINANCING HIGHER EDUCATION IN THE CONTEXT OF LABOUR FORCE MIGRATION: THE CASE OF LITHUANIA
}

\author{
Dainora Grundey $^{1^{*}}$, Miglė Sarvutyté2 \\ Dept of Business Economics and Management, Kaunas Faculty of Humanities, Vilnius University, \\ Muitinès g. 8, LT-44280 Kaunas, Lithuania \\ E-mails: ${ }^{1}$ dainora.grundey@vukhf.lt; ${ }^{2}$ migle.sarvutyte@vukhf.lt
}

Received 11 June 2007; accepted 10 September 2007

\begin{abstract}
This paper aims at presenting a conceptually new model of labour force migration in relation to the higher education policy making and the role of the Government in this process. The concept of human capital development stands out as the main theoretical backbone in this paper, comprising the aspects of financing the higher education and any realities, of how educated specialists could return (if at all) the Government's subsidies provided in their education process, especially in case of their migration to foreign countries. As Lithuania, alongside with other new EU memberstates, such as Poland, Romania, Bulgaria, Hungary, Latvia etc, experiences a 'brain-drain' effect on its labour force market, which, consequently, has a crucial impact on the equilibrium of skilled and unskilled workforce in the listed countries. Therefore the authors raise a question, whether the labour force migration process could be managed, controlled or monitored?
\end{abstract}

Keywords: higher education, financing, human capital, labour force migration, Lithuania.

\section{Introduction}

The implication of labour force in the whole economic system is paramount. In the future, due to the process of regionalisation, which is highly influenced by the globalisation, the labour market might even grow in significance. The process of globalisation underlines knowledge and innovations, economic growth backed up by research and development, which, consequently, requires the increase in numbers of highly skilled specialists. As the global data indicate, the value of the creative class - educated and cosmopolitan employees - would only increase and will play a vital role in regional competitiveness.

Governments need to employ the potential of an effective educational system for ensuring the stability in socioeconomic development, but they also have to consider the fact that high-skilled workers tend to be mobile in search for higher salaries, better working conditions, premiums, quality of life and career prospects.

According to the Dept of Statistics of the Republic of Lithuania, 334000 of Lithuanians emigrated from the country until 2006, but, in fact, this number should be doubled to get a more realistic figure. This paper does not deal with

\footnotetext{
* Corresponding author
}

the causes of migration of the workforce, but it concentrates on the possibility of managing the process of migration.

The scientific problem in this paper is formulated as follows: it is possible to manage the process of workforce migration by effective management systems by proposing a management model of labour force migration, which could ensure the maximum satisfaction of needs for all stakeholders and to ensure the social justice and welfare. The methods applied in this paper incorporate logical generalisation of scientific literature and the application of systems theory.

\section{Economics of higher education}

The economics of higher education goes back at least to Adam Smith, who suggested over 200 years ago in the Wealth of Nations that professors should get paid based upon the number of students enrolled in their classes. In our days there are five categories of education services: primary, secondary, higher, adult and other educations. The most relevant to this report is 'higher' education, which can be described like benefits:

1. Private: Human Capital and Screening theory, Higher Earnings, Status, Life Options, Pleasure, 
Demand for High Skilled Workers.

2. Social: Education and Growth, Education and Democratic Civil Societies, Individual Economic Mobility and Social Justice.

Both at the individual level and the level of society, there is now an ample research showing substantial positive effects of education not only in terms of monetary benefits but also in terms of non-monetary ones [1]. Highly educated people are also more likely to participate in the labour market and have better chances to be employed. In addition to affecting labour-market outcomes, education also affects decisions related to expenditure and savings. Nonmonetary effect approves that education is related to both life-satisfaction and happiness.

On the other hand, the cost sharing (public or private), universities and the industry, brain-drain are very important component parts in this field.

According to human capital theories [2-4] economic effectiveness of education has 3 stages: the evaluation and estimation of costs' structure, the evaluation and estimation of welfare, cost and results comparison. In fact, the cost structure of education comprises the following elements [4]: a) direct costs in the form of education fees; b) conditional costs incur as „lost opportunities” costs, especially for students at higher levels of studies, like Master students; c) direct expenses for the education process incurred the government; d) conditional expenses for education process by the government, calculated as lost taxes from the earnings of potential (lost) salaries by the students. According to the human capital theory, when education is seen as an investment, it is essential to have information about the return on investment for different careers, which can be obtained by the introduction and trading of human capital contracts. Moreover, the transparent pricing mechanism facilitates the establishment of a liquid secondary market, which might lead to reduced illiquidity premium and lower discount rates for investments in human capital [5].

\section{Role of the government in regulating higher education}

The government has a role in the financing, delivery and regulation of higher education - either alone or in partnership with individuals, NGOs and private education. Also, governments must retain their sovereign right to determine own domestic funding and regulatory policies/measures [6]. In New Zealand, the reduction of barriers does not equate to erosion of core public education systems and standards and by the OECD statistical information the government of New Zealand is able to channel more than $2 \%$ of GDP into tertiary education [7]. The principle that the US government should retain the right to regulate to meet domestic policy objectives should be respected, and will continue to play important roles as suppliers of service [8].

The debate will continue about the changing role of government in education, but there is considerable practical innovation and experimentation taking place globally that points to an acceptance of the changing role of govern- ment in educational delivery. Some authors [9] suggest three types of reform: contracting out model (for USA, England), demand-side financing model (in the USA, Chile, Colombia), state-funded private school model (for schools in the USA, Canada, and China, in England and Wales).

\section{Capacity building for managing high-skilled labour force migration}

The migration process could be viewed from the lifecircle perspective, which incorporates the correlation between migration and the conflict [10]. According to Fust (2004), five stages in migration life-circle could be identified. Each stage comprises different causes for migration [11-14], while process itself contains complex relationship between the migrant, and public and private intermediaries, as well as between the transit country and the country of origin. Therefore effective managing the migration demands cooperative efforts of related institutions: governmental, international and non-governmental organisations, the private sector, migrants' communities and migrants themselves. The concept of migration management incorporates policies, laws, directives and public administration, which attempt to guarantee an adequate management of the migration process [15-16]).

From the literature review, five main fields in migration management could be identified. The scientific problem of this paper is closely related to the migration and development phenomenon: the return of the high-skilled to the country of origin, the exchange of know-how, monitory transactions, diaspora, micro-credit schemes, targeted support, the brain-drain problem.

The high-skilled labour force emigration (brain-drain process started in the 1960s) $[12,14,17,18]$, has a directive impact on the country of origin; sunk costs, which were invested in the human capital; qualified specialists lost; the demographical situation worsens; the depletion of social security financing; a steep rise in salaries in those industrial sectors, where the shortage of labour force is most evident. In summary, the loss of high-skilled specialists has a noticeable impact on the country's economy: productivity losses, basic needs for key professions, fiscal losses [19].

A number of scientific papers reflected the outline migration policies $[15,16,20,21]$, as well as suggested tools and means for retaining the migration of high-skilled labour [22-24]). Emigration can be delayed, inhibited, a relaxed, market-driven solution. Another option is to ignore the emigration of skilled workers and let a brain-drain from poorer countries replace lost skills. A more interventionist variation of the market solution is to recruit in target countries while developing immigration incentives, it might be possible to reduce the negative effects of the brain-drain by promoting links with skilled nationals and former nationals abroad [25, 26].

The government, by evaluating the needs in the labour market, should select an appropriate migration management policy. 


\section{Reforms in financing the higher education in Lithuania: realities and perspectives}

The migration realities in Lithuania tend to be gloom; according to the official statistics in 1990-2005:

- 334000 of Lithuanians emigrated from the country (approx 21000 per year), which is about $13 \%$ of economically active labour force;

- the negative migration saldo of 255000 , which is approx 16000 migrants per year;

- the most worrying fact - the undeclared migration of 1990-2000 comprised more than $60 \%$ of total migration flows.

According to the national survey caried out by "Spinter" in 2006-2007, the financing of studies is vital in educating young generation at Lithuanian universities. The majority of survey participants (1003) stated that preferred amount of the money for students at Lithuanian universities and colleges is 860 Litas on average: students get support from their parents (approx 372 Litas) and additionally they earn approx 364 Litas per month, including their scholarship. Over $10 \%$ of the respondents received the financing support from the government (eg orphans) and other public institutions. According to "Spinter" survey, the students spend 713 Litas on average per month.

The survey also showed that a vast majority of respondents $(90 \%)$ entered a higher shool straight after a secondary school graduation $(68,5 \%$ - secondary school graduates and 21,5\%-gymnasium graduates); and they barely have any work experience on the labour market (81,6\%). Even though $35 \%$ of the respondents claim that they are happy with university studies and employment opportunities in Lithuania, they would rather leave the country for a better future.

The new financing reform of higher education in Lithuania aroused lots of discussions. Obviously, the development of the public sector in higher education is only a part of the state's policy in higher education. Some authors claim that the management models of higher education have already been described; therefore Lithuania only needs to adapt one of them. Considering the fact that the migration policy in Lithuania is unique and urgent for explorative solutions, we suggest to include this issue into the management model of higher education. Section 6 is dedicated to this scientific problem, where the migration process is defined in the context of the financing of higher education and the demand for high-skilled specialists.

\section{The conceptual management model of high-skilled labour force}

When researching the migration process from the perspective of investing into the human capital, two main issues are observed: firstly, the investment into the human capital is reasonable until the profit margin equals the profit margin of the best alternative (option), ie an economic subject (an employee, a family, a company or a state) should keep on investing until marginal benefits would equal marginal costs [4]. Secondly, the specific of labour market is important in the context of labour force migration, as it lacks the choice of freedom, which is characteristic of markets of services and goods. The choice of investment in higher education is made in advance to acquired knowledge and skills; and when a high-skilled specialist is lost for a foreign labour market, the state incurs additional costs.

In the long run, the state's policy should be directed towards a) improving the quality of human resources, b) building a favourable environment for running business, c) ensuring the macro-economic stability. The scale of migration directly depends on the economic welfare of the country as the main 'push' and 'pull' factors are that of the economic nature. Considering the effectiveness of the migration process management in the long run, the issue of migration could be tackled alongside the increase of the quality in human resources. The theoretical solution to this problem is proposed by the authors in Fig 1. In order the proposed Model could function, the authors presume the following conditions:

- Presumption 1. The number of places in higher education, funded by the state, should be approved not according to the state's budget but in response to the market demand.

- Presumption 2. The current tuition fee of 4 minimum living standards (500 Litas) should be abolished and the real cost of tuition should be introduced.

- Presumption 3. On entering the university, the tuition contract should be signed with the state and not with the university (note: the issue concerns only state universities).

- Presumption 4. The computerised monitoring system should be introduced and dully maintained.

The proposed Model considers several alternatives: a) when a high-skilled specialist stays in the country and when he/she leaves the country; b) when there is a demand for high-skilled specialists on the labour market and when there isn't.

Some cases, as demonstrated in Fig 2, are beneficial to the state and the employee alike; in other cases, the benefit is experienced by the state and not by the high-skilled specialist. Usually, the decision to emigrate is taken by a specialist on the basis of economic benefits.

Each management process contains four basic functions: planning, organising, managing and controlling. The first three functions have been utilised in the Model already, while the function of control and monitoring is provided in Fig 3.

It is quite too soon to expect real results from the proposed Model; therefore the main accent of this proposition is the forthcoming outcomes $(\mathrm{L})$, which comprise the input criteria for monitoring, determined in Fig 2, and the output criteria resulting in $\mathrm{R}$ (Fig 3 ). As the migration process is a complex scheme, a computerised system is in demand adhered to the integrated functioning of 7 institutions, defined in Fig 3, which have a direct impact on the migration. These institutions receive adequate data from the databank, which enables them to proceed with the decision-making process 


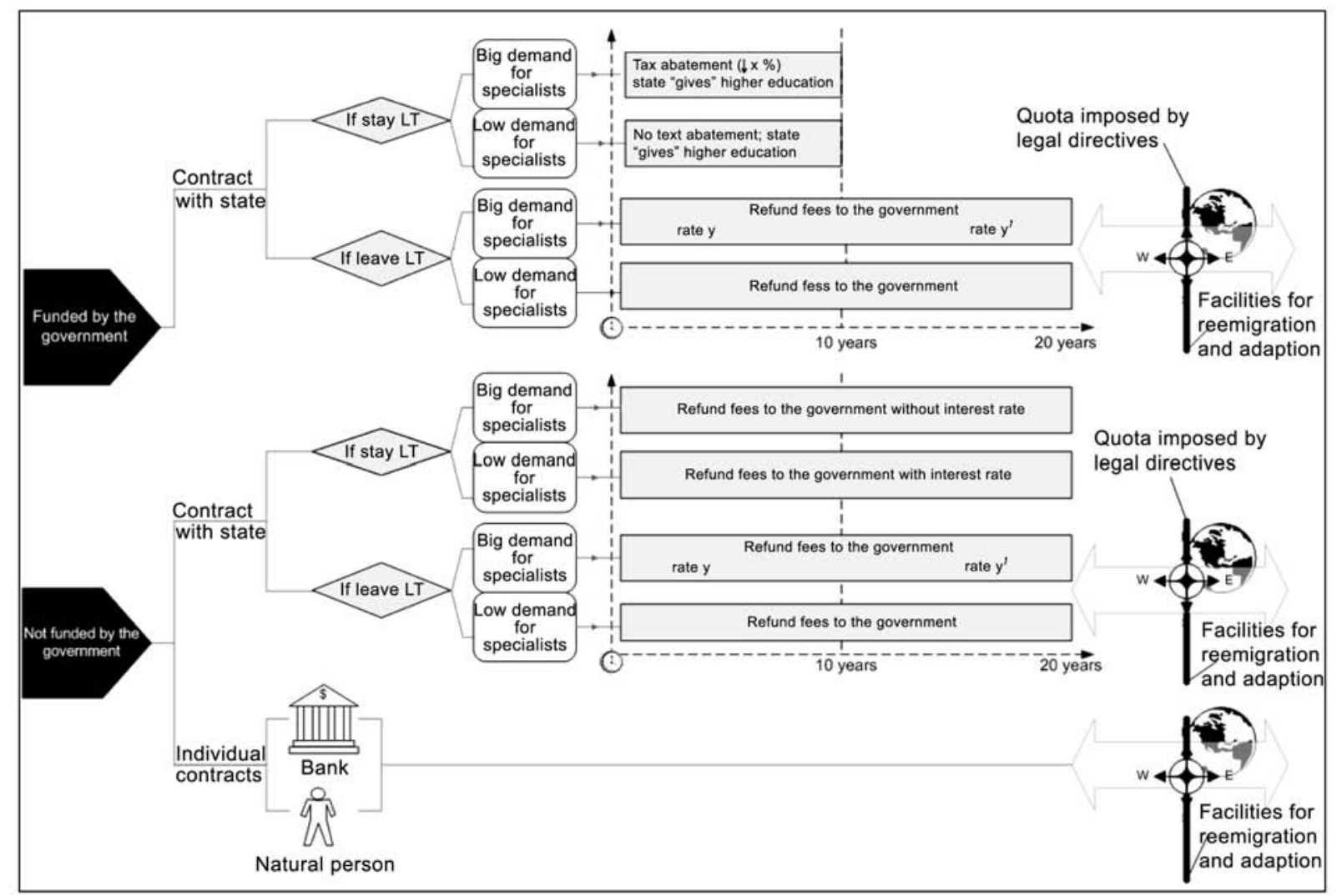

Source: proposed by the authors

Fig 1. The management model of high-skilled labour force migration

(P), as this system evaluates the deviation of real results (RM) from the expected ones $(\mathrm{N}=\mathrm{L}-\mathrm{RM})$. The real data is being processed by experts and analysts, but stakeholders and the general public also have a say. The influence of external effects should be not underestimated as well.

\section{Conclusions}

At first glance the proposed management model of highskilled labour force migration might foster a productive discussion on the levels of governmental, municipal and educational institutions. The arguments may be shaped in the form associations with the feudal times, stating that movement of people is being charged, which might directly contravene the free movement of citizens of the EU, for example. Notwithstanding this situation, a few issues should be taken into consideration. Firstly, market economy should manifest itself in the sphere of attaining higher education, as the value of high-skilled and easily adaptive specialists is on the rise, which, consequently, will become a competitive advantage for any region. Secondly, in Lithuania a misshapen perception of the migration process serves the cause to think that this phenomenon of the $21^{\text {st }}$ century is uncontrollable and vague and does not require any institutional adaptation or a coherent institutional coordination.

\section{References}

1. WÖßMANN, L.; SCHÜTZ, G. Efficiency and equity in European education and training systems. 2006, referred on 12/06/2007, Available from Internet: $<$ http://ec.europa.eu/education/policies/2010/doc/eenee.pdf $>$

2. PIERCE-BROWN, R. An application of human capital theory to salary differentials in the accounting profession. Women in Management Review, 1998, Vol 13, No 5, p. 192-200.

3. COLM, H.; OOSTERBEEK, H.; and WALKER, I. The returns to education: microeconomics. Journal of Economic Surveys, 2003, Vol 17, p. 115-150.

4. BAGDANAVIČIUS, J. Human capital. Vilnius: VPU leidykla, 2002 (in Lithuanian).

5. WELDI, M. Financing higher education cost through human capital contracts - an empirical analysis by subject and degree for Germany. 2007, referred on 12/06/2007, Available from Internet: <zeus.econ.umd.edu/cgi-bin/conference/ download.cgi?db_name $=$ NASM2007\&paper_id $=226>$

6. KNIGHT, J. Trade in higher education services: the implications of GATS. 2002, referred on 29/05/2007, Available from Internet: <www.obhe.ac.uk/products/reports/publicaccesspdf/ March2002.pdf $>$

7. JONGBLOED, B. Funding higher education: options, tradeoffs and dilemmas. Paper for Fulbright Brainstorms 2004 New trends in higher education, 2004.

8. FRIEDMAN, M. The role of government in education, School choices. Referred on 09/06/2007, Available from Internet: $<$ www.schoolchoices.org/roo/fried1.htm> 


\begin{tabular}{|c|c|c|c|c|}
\hline \multicolumn{3}{|c|}{ MODULES } & $\begin{array}{l}\text { COSTS FOR THE STATE /COSTS OR } \\
\text { BENEFITS FOR AN EMPLOYEE }\end{array}$ & BENEFITS \\
\hline \multirow[b]{2}{*}{$\begin{array}{l}\text { Funded by the } \\
\text { govermment }\end{array}$} & \multirow{2}{*}{$\begin{array}{l}\text { Contract } \\
\text { with } \\
\text { state }\end{array}$} & {$\left[\begin{array}{l}\text { Big demand } \\
\text { for specialist }\end{array}\right.$} & $\begin{array}{l}\text { The state fosters the following policies: } \\
\text { employment according to the qualifications } \\
\text { and profession, tax concessions, free higher } \\
\text { education as guaranteed by the Constitution. } \\
\text { By applying these policies, the state in- } \\
\text { creases the psychological dependency, as } \\
\text { the term of concessions extends to } 10 \text { years. }\end{array}$ & $\begin{array}{l}\text { The state is in need of specialists, therefore } \\
\text { the utilities (benefits) they create will su- } \\
\text { persede the investments (various research } \\
\text { proves that the profit margin of the higher } \\
\text { education is } 11 \% \text { ). }\end{array}$ \\
\hline & & $\begin{array}{l}\text { Low demand } \\
\text { of specialist }\end{array}$ & The state provides free higher education. & $\begin{array}{l}\text { It provides economic effectiveness for the } \\
\text { state, as qualified specialists create a high } \\
\text { added value. }\end{array}$ \\
\hline \multirow{2}{*}{$\begin{array}{l}\text { Funded by the } \\
\text { govemment }\end{array}$} & \multirow{2}{*}{$\begin{array}{l}\text { Contract } \\
\text { with } \\
\text { state }\end{array}$} & \multirow[t]{2}{*}{$\begin{array}{l}\text { Big demand } \\
\text { for specialist }\end{array}$} & $\begin{array}{l}\text { The state is in demand of high-skilled spe- } \\
\text { cialists, as the acquired knowledge is 'emi- } \\
\text { grating'. On the other hand, the emigrant is } \\
\text { deprived of any concessions and has to } \\
\text { refund the loaned fee for higher education. }\end{array}$ & $\begin{array}{l}\text { The state is in demand of high-skilled } \\
\text { specialists; thus the emigrants should re- } \\
\text { fund the state's investments into their } \\
\text { higher education by compensating the 'lost' } \\
\text { benefit. This is evaluated by a coefficient, } \\
\text { which differs and depends on whether a } \\
\text { person leaves the country right after his } \\
\text { university studies or some years of experi- } \\
\text { ence. }\end{array}$ \\
\hline & & & $\begin{array}{l}\text { The acquired knowledge is taken out of the } \\
\text { country; therefore the emigrant should } \\
\text { refund his subsidised studies. }\end{array}$ & $\begin{array}{l}\text { The state receives only the investment into } \\
\text { the higher education. }\end{array}$ \\
\hline \multirow{2}{*}{$\begin{array}{l}\text { Not funded by the } \\
\text { government }\end{array}$} & \multirow{2}{*}{$\begin{array}{l}\text { Contract } \\
\text { with } \\
\text { state }\end{array}$} & {$\left[\begin{array}{c}\text { Big demand } \\
\text { for specialist }\end{array}\right.$} & $\begin{array}{l}\text { The state's initiative against the migration } \\
\text { incentive is to provide loans for tuition fees, } \\
\text { and, consequently, this implies that loans } \\
\text { should be paid back. The costs for the state } \\
\text { are higher as it received lower refund due to } \\
\text { the fact that high-skilled specialists stay in } \\
\text { the home country. }\end{array}$ & Refund the tuition fee. \\
\hline & & $\mid \begin{array}{l}\text { Low demand } \\
\text { of specialist }\end{array}$ & $\begin{array}{l}\text { The same costs for the state; the incentive to } \\
\text { remain in the country is relative, but not } \\
\text { essential. }\end{array}$ & $\begin{array}{l}\text { The refunded fee is higher as the interest } \\
\text { rate is inclusive. }\end{array}$ \\
\hline \multirow[b]{2}{*}{$\begin{array}{l}\text { Not funded by the } \\
\text { government }\end{array}$} & \multirow{2}{*}{$\begin{array}{l}\text { Contract } \\
\text { with } \\
\text { state }\end{array}$} & {$\left[\begin{array}{c}\text { Big demanond } \\
\text { for specialist }\end{array}\right]$} & $\begin{array}{l}\text { There might be a shortage of high-skilled } \\
\text { specialists; therefore it is expected the whole } \\
\text { tuition fee will be refunded by the emigrant. }\end{array}$ & $\begin{array}{l}\text { The state receives the refund of tuition fees } \\
\text { and it also compensates according to a } \\
\text { coefficient, which differs and depends on } \\
\text { whether a person leaves the country right } \\
\text { after his university studies or some years of } \\
\text { experience. }\end{array}$ \\
\hline & & \begin{tabular}{|l|} 
Low demand \\
of specialist
\end{tabular} & $\begin{array}{l}\text { The acquired knowledge is taken out of the } \\
\text { country; therefore the emigrant should } \\
\text { refund his subsidised studies. }\end{array}$ & Refund the tuition fee. \\
\hline
\end{tabular}

Note: LT - Lithuania

Source: proposed by the authors

Fig 2. The Models' cost-and-benefit analysis for the state and employees

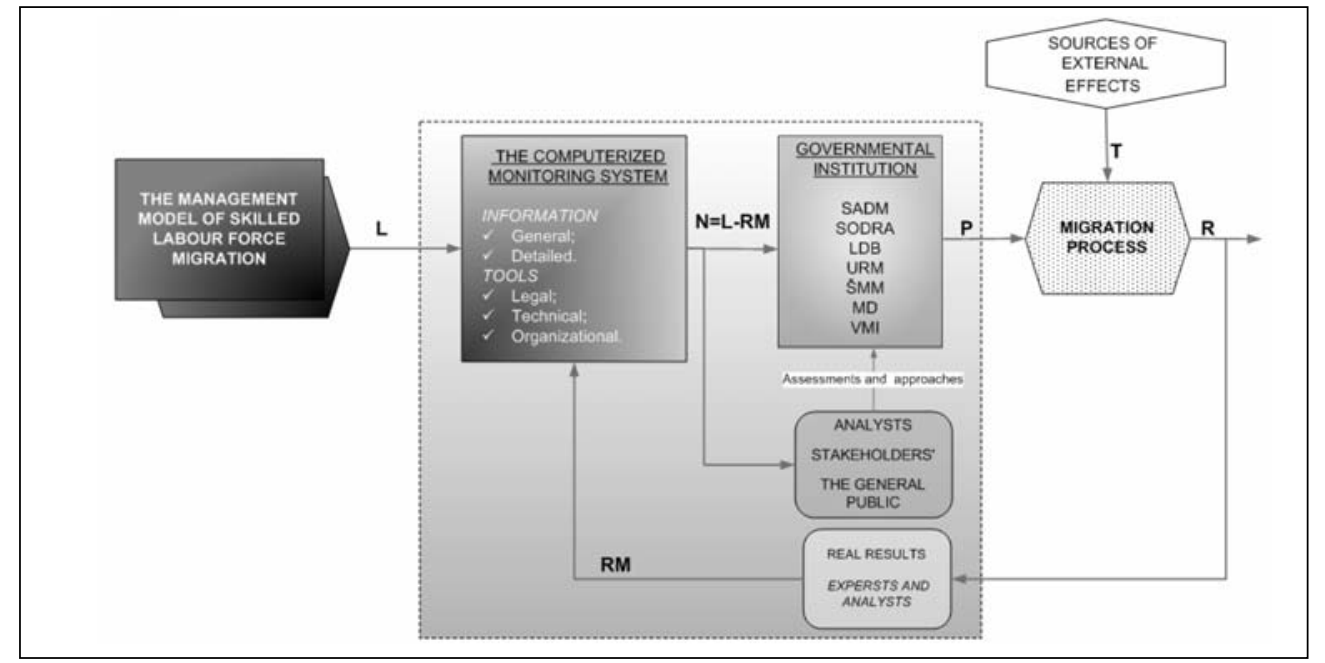

Note: SADM - Ministry of labour and social security; SODRA - State fund for social security; LDB Lithuanian employment office; URM - Ministry of foreign affairs; ŠMM Ministry of education and science, MD - Migration department; VMI - State taxation office

Source: proposed by the authors

Fig 3. The scheme of the working environment of the Model's monitoring system 
9. TOOLEY, J. The changing role of government and education. Education Encyclopedia, 2002.

10. FUST, W. Capacity building for managing migration. In the Berne Initiative Berne II Conference, Berne, 2004.

11. ADOMĖNAS, M. Emigration of Lithuanians: causes, trends and consequences. Conference paper presented in „Emigration from Lithuania: situation, problems, possible solutions“, 18/03/2006 (in Lithuanian).

12. DAUGĖLA, V.; KAZLAUSKIENĖ, A.; SNIEČKA, V. The causes of labour force migration and its specifics in Lithuania. Inžinerine ekonomika, 2000, No 5 (20), p. 17-22 (in Lithuanian).

13. KACZMARCZYK, P.; OKÓLSKI, M. International migration in Central and Eastern Europe - current and future trends, 2004, referred on 18/01/2007, Available from Internet: $<$ www.un.org/esa/population/publications/ittmigdev2005/ P12_Kaczmarczyk\&Okolski.pdf $>$

14. JUNEVIČIUS, A. Free movement of labour force: consequences and impact for the EU and Lithuania. Socialiniai mokslai, 2002, No 1 (33), p. 85-90.

15. IOM (International Organization for Migration). Migration and labour. Essentials of Migration Management, Vol 2: Developing Migration Policy, 2004.

16. SCHOORL, J. Migration policies and integration policies. UNFPA/UNECE/NIDI Training programme on international migration, Geneva, 24-28/01/2005.

17. GLIOSAITĖ, K. Assessment of motives and consequences of economic migrants, 2004. Seminar handouts. Referred on 02/ 12/2005, Available from Internet: <www.civitas.lt/files/ Emigracija_pranesimai.pdf $>$ (in Lithuanian).
18. GNESA, E.; MCKINLEY, B. International agenda for migration management (IAMM). International organisation for migration and federal office for migration, 2004.

19. LUCAS, R. E. B. International migration regimes and economic development. 2004, referred on 12/06/2007, Available from Internet: <www.un.org/esa/population/meetings/ thirdcoord2004/P22_AnnexIII.pdf>

20. MANNING, C. Labour mobility, usiness migration and economic development in the APEC region, 2001, referred on 30/05/2007, Available from Internet: $<$ rspas.anu.edu.au/economics/publish/papers/wp2001/Manning\%202001_03.pdf>

21. WONGBOONSIN, P. Comparative migration policies in the ESCAP region. Labour migration policy and management: Training modules, IOM, 2004.

22. ROBERTSON, S. L. Brain drain, brain gain and brain circulation. Globalisation, Societies and Education, 2006, Vol 4, No 1, p. 1-5.

23. GIANNOCCOLO, P. Brain drain competition policies in Europe: a survey, 2006.

24. NUNN, A. Academic and skilled migration to the UK and its impacts on Africa. 2005, referred on 20/06/2007, Available from Internet: <www.ucu.org.uk/media/pdf/3/4/ thebraindrain.pdf $>$

25. COHEN, R. Brain drain migration. Dept of Sociology, University of Warwick, 1997.

26. HARRIS, N. Economic migration and the European labour market. EPC Issue, Paper No 2 - Part I, 2003.

\section{AUKŠTOJO MOKSLO FINANSAVIMO REIKŠMĖ DARBO JĖGOS MIGRACIJOS KONTEKSTE: LIETUVOS ATVEJIS}

\section{Grundey, M. Sarvutytė}

\section{Santrauka}

Darbo jèga visada buvo svarbi sudètinè ekonominès veiklos dalis, o ateityje dèl vykstančio regionalizacijos proceso, kuriam dideli poveiki daro globalizacija, jos svarba gali dar labiau išaugti. Globalizacija pabréžia inovacijas ir žinias, pramonės augimą, pagristą moksliniais tyrimais, o visam tam reikia didesnio darbuotojų, turinčių daugiau sugebėjimų, skaičiaus. Kaip rodo pasaulio praktika, išsilavinusių, galinčių lengvai adaptuotis ir mokytis darbuotojų vertẻ kyla, nes tokių darbuotojų turejjimas yra pagrindinis regiono ekonomikos pranašumas. Valstybė turi efektyviai panaudoti švietimo potencialą, norėdama užtikrinti ekonominį ir socialinị stabilumą. Tačiau reikia ivvertinti ir toki faktą, kad aukštos kvalifikacijos specialistai yra labai mobilūs. Straipsnyje siūlomas konceptualiai naujas požiūris i kvalifikuotos darbo jègos migracijos valdymą ir jo sąsajas su Vyriausybès plètojama aukštojo mokslo finansavimo politika. Straipsnyje keliama dilema - ar išsilavinę ir migruoti pasirengę Lietuvos specialistai turi grą̌inti i jų studijas investuotas Vyriausybės lèšas.

Reikšminiai žodžiai: aukštasis mokslas, finansavimas, žmogiškasis kapitalas, darbo jègos migracija, Lietuva.

Dainora GRUNDEY. Dr, Assoc Prof. Dept of Business Economics and Management, Kaunas Faculty of Humanities, Vilnius University (Lithuania) and Vice-Dean for Scientific Research and International Relations at the Faculty. Deputy editor-in-chief of "Transformations in Business \& Economics" (ISI rating since 2005) (www.transformations.khf.vu.lt) and editor-in-chief of IJORTISS (http:// ijortiss.vukhf.lt). Member of editorial boards of several international scientific journals. Participant of several international and European projects, including $6^{\text {th }}$ FP MCA project on labour market (2005-09). Coordinator of the INYRSS network (http://inyrss.vukhf.lt). The author of numerous research articles and book chapters (over 140) on marketing, international business and marketing, consumer behaviour, cross-cultural marketing, applications of sustainability in marketing, services and the education system.

Miglè SARVUTYTE். PhD student. Dept of Business Economics and Management, Kaunas Faculty of Humanities, Vilnius University (Lithuania). Technical editor for "Transformations in Business \& Economics" (ISI rating since 2005) (www.transformations.khf.vu.lt) and IJORTISS (http://ijortiss.vukhf.lt). Participant of $6^{\text {th }}$ FP MCA project on labour market (2005-09). The fields of interest include microeconomics, labour market, migration of labour force. 